\title{
Purification of native $\alpha$-enolase from Streptococcus pneumoniae that binds plasminogen and is immunogenic
}

\author{
G. C. WHITING, J. T. EVANS, S. PATEL and S. H. GILLESPIE \\ Department of Medical Microbiology, Royal Free and University College Medical School, London NW3 2PF
}

\begin{abstract}
Many pathogenic bacteria express plasminogen receptors on their surface, which may play a role in the dissemination of organisms by binding plasminogen that, when converted to plasmin, can digest extracellular matrix proteins. A 45-kDa protein was purified from Streptococcus pneumoniae and confirmed as an $\alpha$-enolase by its ability to catalyse the dehydration of 2-phospho-D-glycerate to phosphoenolpyruvate and by $\mathrm{N}$ terminal sequencing. The activity of $\alpha$-enolase was found in the cytoplasm and in whole cells. Activity was also demonstrated in cell wall fractions, which confirmed that $\alpha$ enolase is a cytoplasmic antigen also expressed on the surface of $S$.pneumoniae. The plasminogen-binding activity of $\alpha$-enolase was examined by Western blot, which showed that purified $\alpha$-enolase was able to bind human plasminogen. Immunoblots of the purified 45-kDa $\alpha$-enolase with 22 sera from patients with pneumococcal disease showed binding in 15 cases, indicating that pneumococcal enolase is immunogenic.
\end{abstract}

\section{Introduction}

Streptococcus pneumoniae is a common pathogen of the respiratory tract that causes a wide spectrum of disease in man including otitis media, pneumonia and meningitis [1]. Pneumococcal pneumonia is a major cause of mortality amongst the very young and the elderly and is frequently associated with bacteraemia [1]. To cause meningitis, the pneumococcus must pass through the blood-brain barrier. Bacterial surface proteins play a major role in translocation across tissue barriers. Invasion of host tissue is facilitated by the expression of bacterial surface proteins that adhere to cellular and extracellular ligands [2, 3]. Pneumococci have been shown to adhere to and subsequently migrate across the reconstituted basement membrane of an invitro model system. Migration is thought to be mediated by plasminogen, which can be converted to plasmin, a serine protease, by the action of host urokinase or tissue plasminogen activator (t-PA) [4, 5]. Surface-bound plasmin acquires proteolytic activity, which facilitates the migration of pneumococci through reconstituted basement membranes [4].

Received 14 Jan. 2002; revised version received 17 May 2002; accepted 18 May 2002.

Corresponding author: Professor S.H. Gillespie

(e-mail: stepheng@rfc.ucl.ac.uk).
A $45-\mathrm{kDa}$ protein with strong plasminogen-binding activity has been identified on the surface of $S$. pyogenes and has been shown to have $\alpha$-enolase activity [6]. $\alpha$-Enolase is found in the cytoplasm and is a glycolytic enzyme that catalyses the conversion of phosphoglycerate to phosphoenolpyruvate. It has been demonstrated recently to be present on the surface of most streptococcal species and serotypes and there is some evidence that the pneumococcus binds antienolase antibodies [6].

Several types of gram-positive bacteria, including Staphylococcus aureus, streptococci groups A, C and G and S. dysgalactiae, can bind plasminogen [7-10]. Important gram-negative pathogens including Neisseria meningitidis, Haemophilus influenzae, Borrelia burgdorferi, Salmonella enterica and Helicobacter pylori also bind substantial amounts of plasminogen [11-14]. Surface-bound plasmin enhances penetration of $B$. burgdorferi through artificial endothelial monolayers [15]. Also, plasmin bound to the surface of Sal. enterica is able to degrade extracellular matrix and laminin and can facilitate penetration of the organism through reconstituted basement membrane [16]. An $\alpha-$ enolase has also been identified on the surface of many eukaryotic cells. It has been described on the surface of neuronal, cancer and some haemopoietic cells as a novel plasminogen receptor [17-19] and has been implicated in the invasion of tissue by cells during 
metastasis [17-19]. It has also been described on the cell surface of Candida albicans as an abundant immunodominant antigen [20]. A study performed at the same time as this work has demonstrated that $S$. pneumoniae possesses the sequence for an $\alpha$-enolase and that the protein is expressed on the surface [21]. In this study, the expression of pneumococcal enolase on the surface of the organism and its plasminogenbinding properties were examined. The native protein was purified and the development of antibodies to enolase in patients infected with $S$. pneumoniae was determined.

\section{Materials and methods}

\section{Bacteria and media}

S. pneumoniae strain R36A (NCTC 10319) was grown in Todd Hewitt broth supplemented with yeast extract $0.5 \%$ (THYE).

\section{Purification of $\alpha$-enolase}

Strain R36A was grown to stationary phase at $37^{\circ} \mathrm{C}$ for $16 \mathrm{~h}$ in 8 -L batches of THYE without shaking. Cells were pelleted by centrifugation, washed and resuspended in $10 \mathrm{ml}$ of buffer A, pH $7.4(150 \mathrm{mM} \mathrm{NaCl}$, $50 \mathrm{mM}$ Tris, $1 \mathrm{~mm}$ EDTA, $2 \mathrm{mM}$ DTT, sodium azide $0.025 \%$ ). PMSF was added to a final concentration of $1 \mathrm{mM}$ and the cell suspension was incubated with sodium deoxycholate $1 \%$ for $30 \mathrm{~min}$ at $4^{\circ} \mathrm{C}$ with constant mixing. The extract was centrifuged at $4^{\circ} \mathrm{C}$ for $15 \mathrm{~min}$ at $14000 \mathrm{~g}$ and dialysed against buffer A ( $2 \mathrm{~L}$ total). The concentrated sample was applied to a DE52 column $(120 \times 15 \mathrm{~mm})$ which had been preequilibrated with buffer $\mathrm{A}, \mathrm{pH}$ 7.4. After washing with 10 column volumes of buffer $\mathrm{A}$, the column was sequentially eluted with a $100-\mathrm{ml}$ gradient of 0.15 $0.3 \mathrm{M} \mathrm{NaCl}$ (in buffer A), $50 \mathrm{ml}$ of $0.3 \mathrm{M} \mathrm{NaCl}$ (in buffer A) and $25 \mathrm{ml}$ of $0.4 \mathrm{M} \mathrm{NaCl}$ (in buffer A). Fractions with $\alpha$-enolase activity were pooled $(50 \mathrm{ml})$ and concentrated five-fold by ultra-filtration through a $10-\mathrm{kDa}$ cut-off membrane (Amicon). The resulting sample was concentrated five-fold by acetone precipitation. This 2-ml sample was applied to a FPLC gel filtration Sephadex G-25M column (Pharmacia PD-10) and eluted with $4 \mathrm{ml}$ of buffer A. $\alpha$-Enolase activity was determined in each fraction by the coupled enzyme activity assay described below. Protein elution profile in each fraction was determined by SDS-PAGE and Coomassie Blue staining. Protein concentration was determined by the bicinchonic acid (BCA) method (Pierce) with bovine serum albumin (BSA) as standard.

\section{$N$-terminal sequencing}

The N-terminal amino acid sequence of the purified 45$\mathrm{kDa}$ protein was determined as follows. The $45-\mathrm{kDa}$ protein was resolved by SDS-PAGE on an acrylamide $12 \%$ gel and electroblotted on to polyvinylidene membrane (Immobilon-P; Millipore). The protein was visualised by staining with Ponceau S (Sigma) $0.1 \%$ in $1 \%$ acetic acid. The portion of the membrane containing the band of interest was excised, destained with distilled water and subjected to automated Edman degradation at the Protein Sequencing Facility, University of Aberdeen.

\section{$\alpha$-Enolase activity}

$\alpha$-Enolase activity was measured by a coupled assay described previously which measures the transformation of NADH to NAD [6]. The assay was performed at $37^{\circ} \mathrm{C}$ in $100 \mathrm{mM}$ HEPES buffer, $\mathrm{pH} 7.0$, containing $5.0 \mathrm{mM} \mathrm{MgSO}_{4}, 0.2 \mathrm{mM} \mathrm{NADH}, 0.25 \mathrm{mM}$ 2-phosphoglycerate (2-PGE), $1.2 \mathrm{mM}$ ADP, lactate dehydrogenase $10.7 \mathrm{IU}$ and pyruvate kinase $2.5 \mathrm{IU}$ in a final reaction volume of $1.0 \mathrm{ml}$. The reaction was started by adding $100 \mu \mathrm{l}$ of the test solution containing $\alpha$-enolase and $\alpha$ enolase activity was determined by measuring the rate of reduction in absorbance at $340 \mathrm{~nm}$ (i.e., the increase in production of NAD). Protein concentrations were determined by the bicinchoninate acid protein assay (Pierce) to calculate specific activities expressed as $\mu \mathrm{mol} \mathrm{NADH}$ oxidised $/ \mathrm{min} / \mathrm{mg}$ of extract.

\section{Surface $\alpha$-enolase activity}

$\alpha$-Enolase activity on whole $S$. pneumoniae. To determine whether the $\alpha$-enolase-like molecule was expressed on the surface of $S$. pneumoniae, cells from a 20-ml stationary phase (16-h) culture of R36A were harvested by centrifugation and washed three times in $100 \mathrm{mM}$ HEPES, pH 7.0. The whole pneumococci were serially diluted so that different numbers of pneumococci were incubated in the coupled assay for $\alpha$ enolase described above with or without $0.25 \mathrm{mM}$ 2-PGE. The bacteria were incubated in a final volume of $1 \mathrm{ml}$ for $5 \mathrm{~min}$ at $37^{\circ} \mathrm{C}$. A negative control consisting of tubes without pneumococcal cells was included. The whole bacteria were removed by centrifugation and the supernates were analysed by measuring absorbance at $340 \mathrm{~nm}$.

Fractionation of $S$. pneumoniae. S. pneumoniae strain R36A was grown to mid-exponential phase at $37^{\circ} \mathrm{C}$ in $20 \mathrm{ml}$ of THYE. The subcellular components were fractionated with mutanolysin by the method of Yother and White [22]. Cells from a 1.5-ml sample were pelleted by centrifugation and the supernate was filtered $(0.2 \mu \mathrm{m}$ filter $)$ and reserved. The pellet was washed in 0.5 culture volumes of $\mathrm{H}_{2} \mathrm{O}$ and resuspended in 0.2 culture volumes of protoplast buffer (sucrose $20 \%, 5 \mathrm{~mm}$ Tris, $\mathrm{pH} 7.4,2.5 \mathrm{mM} \mathrm{MgSO}_{4}$ ) containing mutanolysin (Sigma) $25 \mu \mathrm{g} / \mathrm{ml}$. After incubation for $1 \mathrm{~h}$ at $37^{\circ} \mathrm{C}$, the protoplasts were removed by centrifugation ( $3000 \mathrm{~g} 10 \mathrm{~min}$ ) and the supernate containing the cellwall material was filtered and reserved. The pellet was washed once in 0.2 culture volumes of protoplast buffer 
and the protoplasts were lysed by resuspension in 0.2 culture volumes of $\mathrm{H}_{2} \mathrm{O}$. Membranes were removed by centrifugation (13000 g, for $2 \mathrm{~min}$ ) and the supernate containing the cytoplasmic contents was filtered and reserved. The membranes were washed in 0.2 culture volumes of $\mathrm{H}_{2} \mathrm{O}$. Peripheral membrane proteins were released by washing in 0.2 culture volumes of $0.1 \mathrm{M}$ $\mathrm{Na}_{2} \mathrm{CO}_{3}$, pH 11.2. Choline-associated proteins were removed by washing with 0.2 culture volumes of choline $2 \%$. The pellet was finally resuspended in 0.2 culture volumes of $\mathrm{H}_{2} \mathrm{O}$. Equivalent amounts of all fractions, representing $100 \mu \mathrm{l}$ of unconcentrated culture, were assayed for $\alpha$-enolase activity.

SDS-PAGE and Western blotting. Proteins were separated by SDS-PAGE. Samples were applied to acrylamide $12 \% \mathrm{w} / \mathrm{v}$ gels and run on a mini vertical gel apparatus (BioRad) at a constant voltage of $175 \mathrm{~V}$. After electrophoresis, the gels were prepared for protein transfer to nitrocellulose membrane by equilibration in transfer buffer containing $20 \mathrm{mM}$ Tris, $192 \mathrm{~mm}$ glycine, methanol 20\% v/v, $\mathrm{pH} 8.3$. Electrophoretic transfer was performed for $1 \mathrm{~h}$ at constant current (area of gel $\mathrm{cm}^{2} \times 0.8 \mathrm{~mA}$ ) in a semi-dry blotter (LKB) with a transfer buffer. After transfer, blots were stained for protein in Ponceau's Reagent (Sigma) for $10 \mathrm{~min}$ at room temperature.

To detect plasminogen-binding activity, the membranes were blocked for $1 \mathrm{~h}$ with Tris-buffered saline (TBS: $20 \mathrm{~mm}$ Tris $\mathrm{HCl}, \mathrm{pH}, 500 \mathrm{mM} \mathrm{NaCl}$ ) containing bovine serum albumin (BSA) 3\%. After extensive washing in TBS containing Tween-20 $0.05 \%$ (TBST), blots were incubated overnight at $4{ }^{\circ} \mathrm{C}$ with human plasminogen (Sigma) $4 \mu \mathrm{g} / \mathrm{ml}$ in TBST-BSA $1.0 \%$. After washing in TBST blots were incubated in TBSTBSA $1.0 \%$ containing a 1 in 1000 dilution of goat antihuman plasminogen (ICN) for $2 \mathrm{~h}$. The bound antibody was revealed by incubating blots with anti-goat $\mathrm{IgG}$ HRP conjugate (Sigma). Antiserum binding was visualised by use of the ECL fluorescent labelling kit and the chemiluminescent exposure of X-ray film (Amersham).

\section{Patients and sera}

Sera from 22 patients at the Royal Free Hospital with invasive pneumococcal disease (bacteraemia), were collected and used in Western blot analysis of pneumococcal proteins. The membranes were blocked for $1 \mathrm{~h}$ with TBS-BSA 3\%. After extensive washing in TBST the blot was incubated overnight at $4^{\circ} \mathrm{C}$ with an appropriate dilution of human serum in TBST-BSA $1.0 \%$. After washing in TBST, the bound antibody was revealed by treating with anti-human IgG HRP conjugate. Antiserum binding was visualised as described above.

\section{Results}

\section{$N$-terminal amino acid sequence and identification of the 45-kDa protein as an $\alpha$-enolase enzyme}

The $45-\mathrm{kDa}$ protein was partially purified from the cell-wall extract by ion-exchange chromatography on a DE52 column. It was further concentrated and purified by ultra-filtration and acetone precipitation. After FPLC gel filtration, N-terminal amino acid sequencing of the $45-\mathrm{kDa}$ protein revealed the following 30 residues:SIITDVYAREVLDSRGNPTLEVGVYTESGA. Comparison of this 30-amino acid N-terminal sequence with the genomic sequence database of $S$. pneumoniae (www.tigr.org) revealed $100 \%$ homology to the $\mathrm{N}$ terminal region of a 1305-bp open reading frame of $S$. pneumoniae, with the exception of the amino terminal methionine (accession no. AE005672) [23]. Furthermore, the first 50 residues of the $\mathrm{N}$-terminal sequence showed $96 \%$ identity to the N-terminal region of the $S$. pyogenes $\alpha$-enolase [6]. The $S$.pyogenes $\mathrm{N}$-terminal sequence was $100 \%$ identical to an open reading frame from the genome sequence database (accession no. AE004092) [24]. The predicted molecular mass of the $S$. pneumoniae $\alpha$-enolase protein is $47.1 \mathrm{kDa}$. This corresponds to the observed molecular mass of $45 \mathrm{kDa}$ on SDS-PAGE.

\section{$\alpha$-Enolase activity}

To confirm that the $45-\mathrm{kDa}$ protein was an $\alpha$-enolase, its activity was assayed in a coupled enzyme assay for enolase. The $45-\mathrm{kDa}$ protein was demonstrated to convert NADH to NAD resulting in a change in absorbance at $340 \mathrm{~nm}$. This indicated that pyruvate was converted to lactate and NADH by lactate dehydrogenase, confirming the conversion of phosphoglycerate to phosphoenolpyruvate by $\alpha$-enolase and finally to pyruvate in the presence of externally provided pyruvate kinase and ADP in a sequential manner. These data are illustrated in Fig. 1.

\section{$\alpha$-Enolase activity of intact pneumococci}

To determine whether the $\alpha$-enolase activity of the 45$\mathrm{kDa}$ protein is expressed on the pneumococcal surface, enzymic activity was examined by the coupled enzyme assay with intact pneumococci in the presence or absence of $2.5 \mathrm{~mm}$ 2-phosphoglycerate. The results shown in Fig. 2 revealed a dose-dependent $a$-enolase activity catalysed by the intact cells in the presence of 2-phosphoglycerate. Intact pneumococci did not catalyse any detectable reaction in the absence of the substrate. These results suggest that the $45-\mathrm{kDa}$ protein is expressed on the surface. To confirm that enolase activity is associated with the cell wall, subcellular fractions were prepared and assayed for $\alpha$-enolase activity. The results shown in Fig. 3 demonstrate that, as expected, there is evidence of $\alpha$-enolase activity associated with the cytoplasmic fraction. There was 


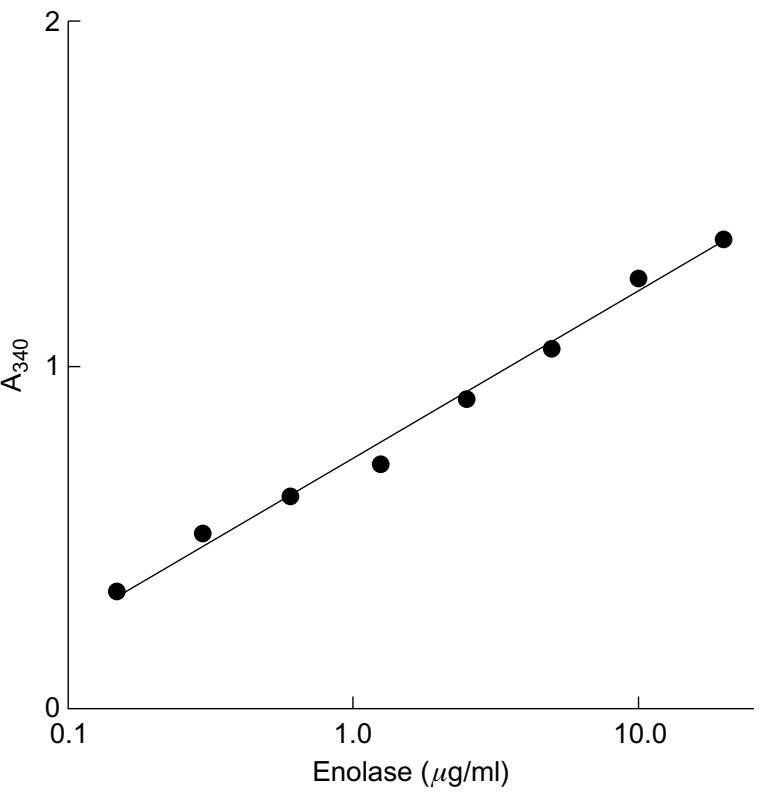

Fig. 1. $\alpha$-Enolase activity of $S$. pneumoniae. The $\alpha$-enolase activity of the purified $45-\mathrm{kDa}$ protein was measured in a coupled enzyme assay catalysing the conversion of 2-phosphoglycerate to phosphoenol pyruvate. The decrease in absorbance at $340 \mathrm{~nm} / \mathrm{min}$ corresponded to the rate of conversion of $\mathrm{NADH}$ to $\mathrm{NAD} / \mathrm{min}$. Experiments were performed in triplicate and the mean value was plotted.

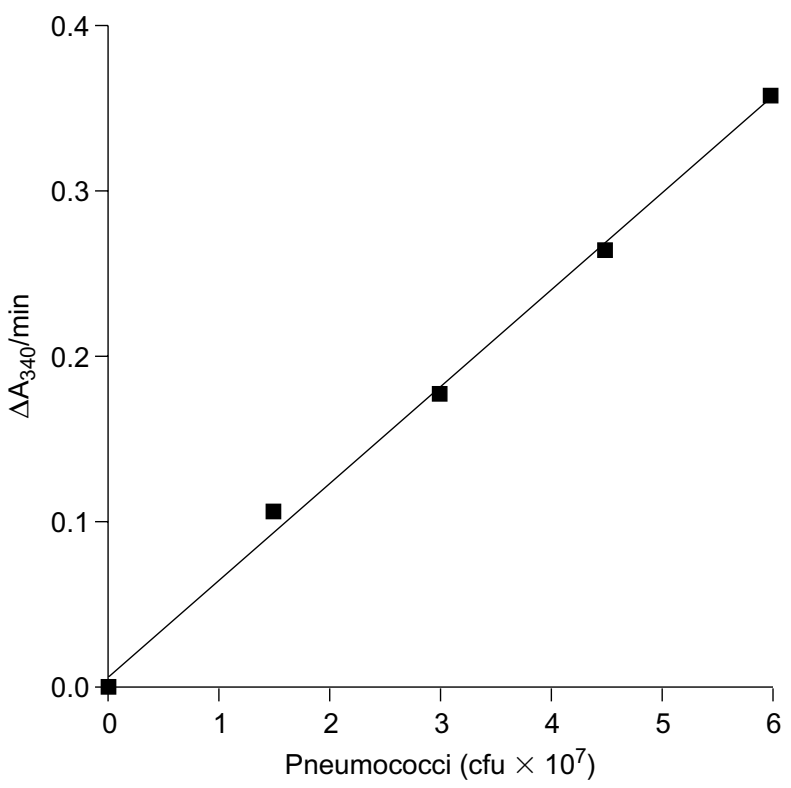

Fig. 2. $\alpha$-Enolase activity in whole $S$. pneumoniae cells. The $\alpha$-enolase activity of intact cells was measured in a coupled enzyme assay catalysing the conversion of 2-phosphoglycerate to phosphoenol pyruvate. The decrease in absorbance at $340 \mathrm{~nm} / \mathrm{min}$ corresponded to the rate of conversion of NADH to $\mathrm{NAD} / \mathrm{min}$. Experiments were performed in triplicate and the mean value was plotted.

also significant activity in the cell-wall fraction, but little associated with either the supernate or various membrane fractions.

\section{Plasminogen binding}

The plasminogen-binding activity of the $45-\mathrm{kDa} \alpha-$

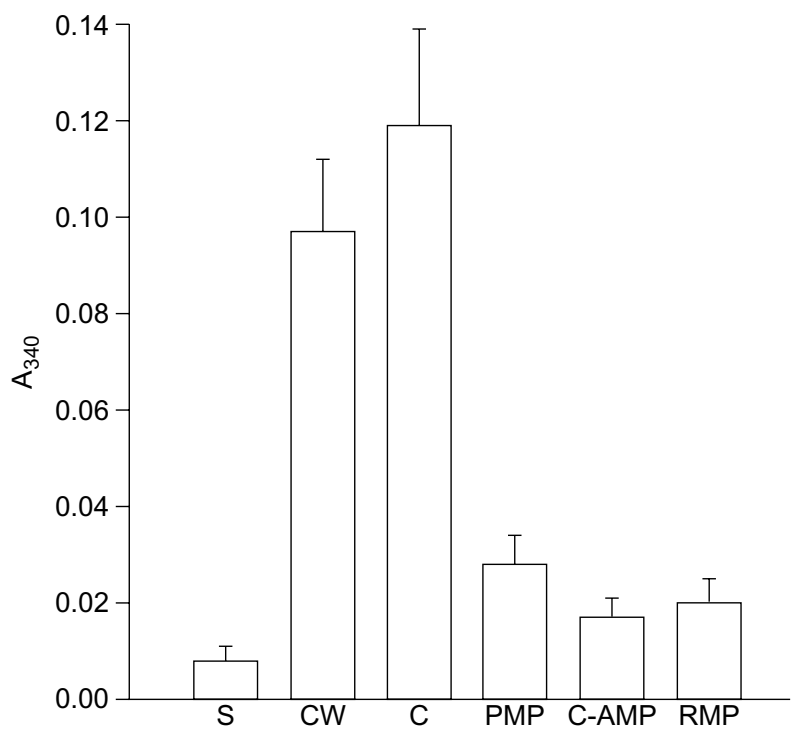

Fig. 3. $\alpha$-Enolase activity of subcellular fractions of $S$. pneumoniae. The $\alpha$-enolase activity of subcellular fractions was measured in a coupled enzyme assay catalysing the conversion of 2-phosphoglycerate to phosphoenol pyruvate. The decrease in absorbance at $340 \mathrm{~nm} / \mathrm{min}$ corresponded to the rate of conversion of $\mathrm{NADH}$ to $\mathrm{NAD} / \mathrm{min}$. Experiments were performed in triplicate and the mean value was plotted. S, supernate; $\mathrm{CW}$, cell wall; $\mathrm{C}$, cytoplasm; PMP, peripheral membrane proteins; C-AMP, choline-associated membrane proteins; RMP, residual membrane proteins.

enolase was examined by Western blot. Purified $\alpha$-enolase was incubated with human plasminogen. The results of the detection of plasminogen are shown in Fig. 4 and demonstrate that $\alpha$-enolase has plasminogen-binding activity.

\section{Screening of human sera for antibody to $\alpha$ - enolase}

Western blots of purified $\alpha$-enolase were performed with sera from 22 patients with pneumococcal disease. Serum from 15 of these patients reacted with $\alpha$ enolase. Representative blots are shown in Fig. 5.

\section{Discussion}

Pneumococcal infection is preceded by colonisation of the nasopharyngeal epithelium, an interaction that is partially mediated by the $37-\mathrm{kDa}$ surface protein PsaA binding to epithelial cell glycoproteins [25]. If the protective measures of the host do not result in clearance at this stage, a progression to the lower respiratory tract may occur. The pneumococci will then proliferate within the alveoli and potentially invade the bloodstream. In-vitro studies revealed that $S$. pneumoniae initially attaches to vascular endothelial cells via two classes of glycoconjugates [26, 27]. Subsequent invasion of human endothelial cells is promoted by cytokine activation which increases the amount of surface-expressed platelet-activating factor (PAF) re- 


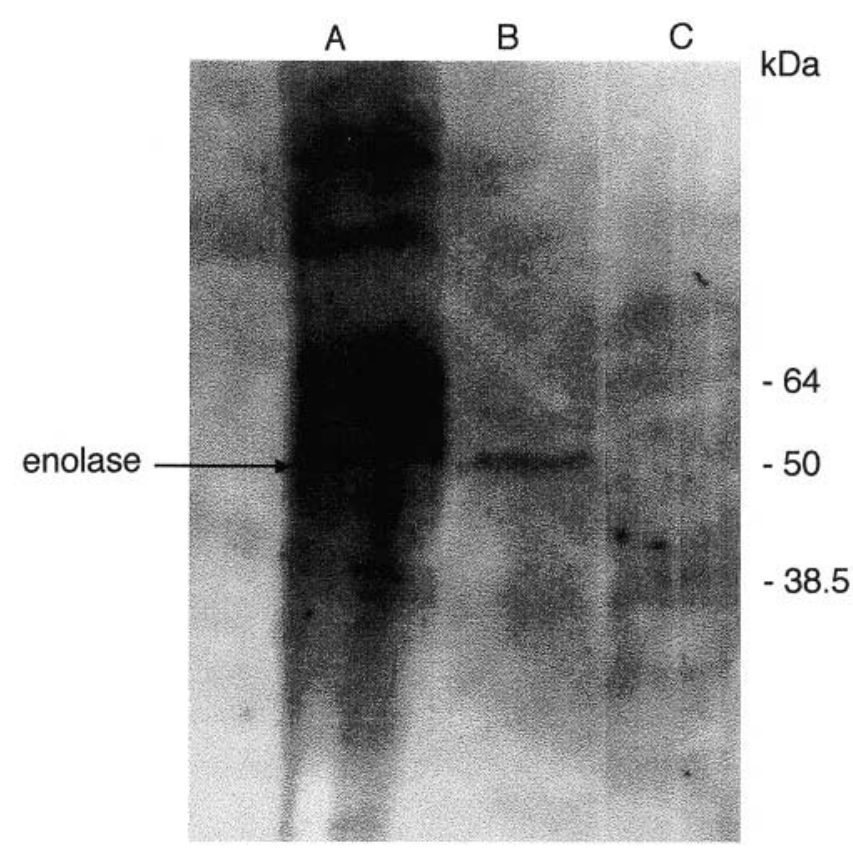

Fig. 4. Identification of $\alpha$-enolase as a plasminogen-binding protein. (A) Whole-cell lysate, (B) purified $\alpha$-enolase, (C) the position of each mol. wt standard is provided in $\mathrm{kDa}$.

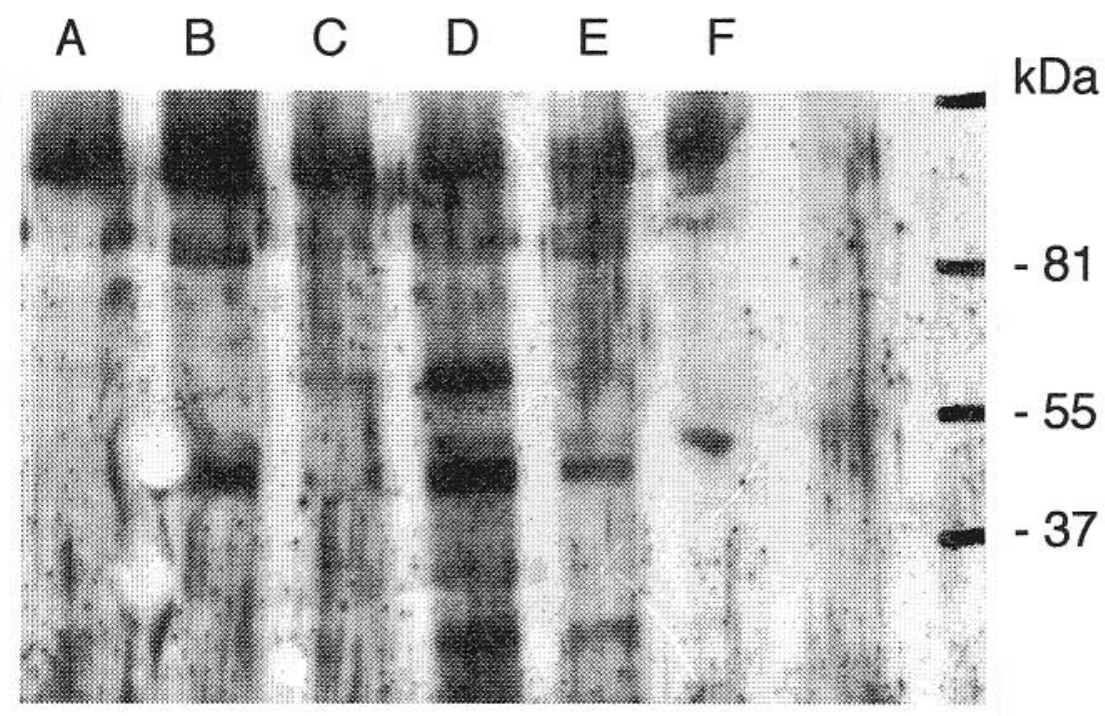

Fig. 5. Screening of human sera for antibody to $\alpha$-enolase. Purified $\alpha$-enolase is shown after Western blotting with patients' sera. Representative blots with serum from three patients are shown. Lanes $\mathbf{A}, \mathbf{C}$ and $\mathbf{F}$ are negative; lanes $\mathbf{B}, \mathbf{D}$ and $\mathbf{E}$ are positive. The position of each mol. wt standard is provided in $\mathrm{kDa}$.

ceptor that in turn binds to the phosphorylcholine component of the cell wall [28]. An adhesin CbpA promotes increased attachment to activated human cells [29]. Recent studies showed that pneumococci could bind to reconstituted basement membrane as well as to a purified laminin component [4]. Furthermore, they can bind other extracellular matrix components such as fibronectin, laminin, collagen and vitronectin [30, 31]. The acquisition of proteolytic activity on the surface by the capture of plasminogen and subsequent activation to plasmin by host t-PA can be used by the pneumococcus to penetrate biological membranes more rapidly [32]. This improvement in bacterial migration would not only result in dissemination into the bloodstream but would promote the passage of pneumococci across the blood-brain barrier.

A recent report has demonstrated that $S$. pneumoniae has an $\alpha$-enolase and that recombinant protein activates plasminogen [21]. The present study confirmed and extended this observation by purifying a $45-\mathrm{kDa}$ protein and showing that it is an $\alpha$-enolase and that it is expressed on the surface of the bacterium as well as in the cytoplasm. Comparison of the $\mathrm{N}$-terminal 
amino acid sequence of this protein with the $S$. pneumoniae and $S$. pyogenes partial genome databases confirmed that the $\alpha$-enolase had been purified.

The pneumococcal $\alpha$-enolase is a plasminogen-binding protein similar to the enolase that has been described on the surface of $S$. pyogenes $[6,21]$ and surface plasminogen activation has been described in $S$. pneumoniae [4]. The plasminogen system plays an important role in host defence by dissolving fibrin clots and maintaining homeostasis and vascular patency. The 92-kDa plasma protein, plasminogen, is a single-chain glycoprotein with a glutamic acid residue at its amino terminus (Glu-plasminogen) which is readily processed to a modified form containing a lysine residue at its amino terminus (Lys-plasminogen). The inactive proenzyme binds via its lysine-binding sites to the fibrin molecule and is converted to the active plasmin serine protease by plasminogen activators such as urokinase and host t-PA. Removal of the terminal lysines from $\alpha$ enolase results in an abrogation of plasminogen binding [21]. Group A, C and G streptococci can express up to 50000 high affinity binding sites per bacterium for plasminogen with $\mathrm{K}_{\mathrm{d}}$ values in the range of $20-80 \mathrm{nM}$ and S.pneumoniae have up to 10000 sites with $\mathrm{K}_{\mathrm{d}}$ values of $60 \mathrm{mM}$ [32]. Group $\mathrm{G}$ streptococci also express low affinity binding similar to that demonstrated for $S$. pneumoniae with up to 14000 low affinity binding sites with $\mathrm{K}_{\mathrm{d}}$ values of $300 \mathrm{mM}$ [33]. Important gram-negative pathogens such as $N$. meningitidis, $H$. influenzae, B. burgdorferi and $H$. pylori also bind substantial amounts of plasminogen [11-14]. For group A, C and G streptococci and in most other cases, plasminogen binding to the bacterial surface leads to a greatly enhanced rate of t-PA-mediated activation [9, 33]. Physiological plasmin inhibitors such as $a_{1}$ - and $a_{2}$-antiplasmin are no longer able to inhibit the proteolytic activity of surface-bound plasmin [34, 35]. The plasminogen system may thus be subverted by pathogens to allow tissue invasion. Bacterial binding of plasminogen has been reported to facilitate bacterial penetration in different systems. Increased transcytosis of Staph. aureus across mammary epithelial cell monolayers has been demonstrated [36]. The addition of plasminogen to cultures of $B$. burgdorferi can enhance penetration of endothelial cell monolayers [15]. A surface-associated plasminogen activator pla is an important virulence factor for Yersinia pestis, enabling migration through dermal tissue [37].

The ability of $\alpha$-enolase to bind plasminogen demonstrated here supports the idea that this antigen may be responsible in part for the plasminogen activity that has already been demonstrated on the surface of $S$. pneumoniae [4]. It also means that $\alpha$-enolase may be responsible, in part, for the ability of $S$. pneumoniae to cross tissue barriers [4].

The finding that 15 of 22 patients with proven $S$. pneumoniae infection have antibodies to $\alpha$-enolase is of considerable importance. The immune response demonstrated may have occurred due to a response to the current or a previous pneumococcal infection. Alternatively, the $\alpha$-enolase of $S$. pneumoniae is highly homologous with that of other streptococci [6] and thus patients may have acquired antibodies by infection with these organisms. $\alpha$-Enolases may have an important role in natural immunity to $S$. pneumoniae but the role of antibodies to $\alpha$-enolase in prevention of pneumococcal infection will require further study. Like the response to other non-capsule antigens, such antibodies could not provide sterile immunity. The critical role of plasminogen activation in migration across tissue barriers may mean that anti-enolase antibodies may be important as an adjunctive vaccine.

In summary, penetration of basement membrane is believed to be an essential step in the pathogenesis of bacterial meningitis and thus it is clear that the ability of pathogenic bacteria to express plasminogen-binding proteins may be an important determinant of virulence. Although the results of the present study do not exclude the possibility of other plasminogen-binding proteins, the data indicate that plasminogen binds to $\alpha$ enolase and this may be responsible for its subsequent activation on the pneumococcal surface. This may facilitate penetration through biological membranes and thus implies that this antigen may have an important role in the development of invasive disease.

This study was funded by a grant from the Wellcome Trust. We gratefully acknowledge the critical review of the manuscript provided by Professor Brian Henderson and Dr Bambos Charalambous.

\section{References}

1. Balakrishnan I, Crook P, Morris R, Gillespie SH. Early predictors of mortality in pneumococcal bacteraemia. $J$ Infect 2000; 40: 256-261.

2. Westerlund B, Korhonen TK. Bacterial proteins binding to the mammalian extracellular matrix. Mol Microbiol 1993; 9: 687-694.

3. Patti JM, Allen BL, McGavin MJ, Höök M. MSCRAMMmediated adherence of microorganisms to host tissues. Annu Rev Microbiol 1994; 48: 535-617.

4. Eberhard T, Kronvall G, Ullberg M. Surface bound plasmin promotes migration of Streptococcus pneumoniae through reconstituted basement membranes. Microb Pathog 1999; 26: $175-181$.

5. Dan K, Andreason PA, Grondhal-Hansen P, Kristensen P, Neilsen LA, Skiver L. Plasminogen activators, tissue degradation and cancer. Adv Cancer Res 1985; 44: 139-266.

6. Pancholi V, Fischetti VA. A-Enolase, a novel strong plasmin(ogen) binding protein on the surface of pathogenic streptococci. J Biol Chem 1998; 273: 14503-14515.

7. Ullberg M, Kronvall G, Wiman B. New receptor for human plasminogen on gram-positive cocci. APMIS 1989; 97: 9961002.

8. Kuusela P, Saksela O. Binding and activation of plasminogen at the surface of Staphylococcus aureus. Increase in affinity after conversion to the Lys form of the ligand. Eur $J$ Biochem 1990; 193: 759-765.

9. Kuusela P, Ullberg M, Saksela O, Kronvall G. Tissue-type plasminogen activator-mediated activation of plasminogen on the surface of group A, C, and G streptococci. Infect Immun 1992; 60: 196-201.

10. Leigh JA, Hodgkinson SM, Lincoln RA. The interaction of Streptococcus dysgalactiae with plasmin and plasminogen. Vet 
Microbiol 1998; 61: 121-135.

11. Ullberg M, Kronvall G, Karlsson I, Wiman B. Receptors for human plasminogen on Gram negative bacteria. Infect Immun 1990; 58: 21-25.

12. Ullberg M, Kuusela P, Kristiansen B-E, Kronvall G. Binding of plasminogen to Neisseria meningitidis and Neisseria gonorrhoeae and formation of surface-associated plasmin. J Infect Dis 1992; 166: 1329-1334.

13. Fuchs H, Wallich R, Simon MM, Kramer MD. The outer surface protein A of the spirochete Borrelia burgdorferi is a plasmin(ogen) receptor. Proc Natl Acad Sci USA 1994; 91: 12594-12598.

14. Tingner M, Valkonen KH, Wadström T. Binding of vitronection and plasminogen to Helicobacter pylori. FEMS Immunol Med Microbiol 1994; 9: 29-34.

15. Coleman JL, Sellati TJ, Testa JE, Kew RR, Furie MB, Benach JL. Borrelia burgdorferi binds plasminogen, resulting in enhanced penetration of endothelial monolayers. Infect Immun 1995; 63: 2478-2484.

16. Lähteenmäki K, Virkola R, Pouttu R, Kuusela P, Kukkonen M, Korhonen TK. Bacterial plasmin receptors: in vitro evidence for a role in degradation of the mammalian extracellular matrix. Infect Immun 1995; 63: 3659-3664.

17. Nakajima K, Hamanoue M, Takemoto N, Hattori T, Kato K, Kohsaka S. Plasminogen binds specifically to $\alpha$-enolase on rat neuronal plasma membrane. $J$ Neurochem 1994; 63: $2048-$ 2057.

18. Lopez-Alemany R, Correc P, Camoin L, Burtin P. Purification of the Plasmin receptor from human carcinoma cells and comparison to alpha-enolase. Thromb Res 1994; 75: 371-381.

19. Miles LA, Dahlberg CM, Plescia J, Felez J, Kato K, Plow EF. Role of cell-surface lysines in plasminogen binding to cells: identification of $\alpha$-enolase as a candidate plasminogen receptor. Biochemistry 1991; 30: 1682-1691.

20. Angiolella L, Facchin M, Stringaro A, Maras B, Simonetti N, Cassone A. Identification of a glucan-associated enolase as a main cell wall protein of Candida albicans and an indirect target of lipopeptide antimycotics. J Infect Dis 1996; 173: 684-690.

21. Bergmann S, Rohde M, Chatwal GS, Hammerschmidt S. $\alpha$ enolase of Streptococcus pneumoniae is a plasmin(ogen)binding protein displayed on the bacterial cell surface. Mol Microbiol 2001; 40: 1273-1287.

22. Yother Y, White JM. Novel surface attachment mechanism of the Streptococcus pneumoniae protein PspA. J Bacteriol 1994; 176: $2976-2985$.

23. Ferretti JJ, McShan WM, Ajdic D et al. Complete genome sequence of an M1 strain of Streptococcus pyogenes. Proc Natl Acad Sci USA 2001; 98: 4658-4663.
24. Tettelin H, Nelson KE, Paul IT et al. Complete genome sequence of a virulent isolate of Streptococcus pneumoniae. Science 2001; 293: 498-506.

25. Berry AM, Paton JC. Sequence heterogeneity of PsaA, a 37 kilodalton putative adhesin essential for virulence of Streptococcus pneumoniae. Infect Immun 1996; 64: 5255-5262.

26. Andersson B, Eriksson B, Falsen E et al. Adhesion of Streptococcus pneumoniae to human pharyngeal cells in vitro: differences in adhesive capacity among strains isolated from subjects with otitis media, septicemia, or meningitis or from healthy carriers. Infect Immun 1981; 32: 311-317.

27. Krivan HC, Roberts DD, Ginsburg V. Many pulmonary pathogenic bacteria bind specifically to the carbohydrate sequence GalNAc $\beta 1-4$ Gal found in some glycolipids. Proc Natl Acad Sci USA 1988; 85: 6157-6161.

28. Cundell DR, Gerard NP, Gerard C, Idänpään-Heikkilä I, Tuomanen EI. Streptococcus pneumoniae anchor to activated human cells by the receptor for platelet-activating factor. Nature 1995; 377: 435-438.

29. Rosenow C, Ryan P, Weiser JN et al. Contribution of novel choline-binding proteins to adherence, colonization and immunogenicity of Streptococcus pneumoniae. Mol Microbiol 1997; 25: 819-829.

30. Kostrzynska M, Wadstrom T. Binding of laminin, type IV collagen, and vitronectin by Streptocccus pneumoniae. Zentralbl Bakteriol 1992; 277: 80-83.

31. van der Flier M, Chhun N, Wizemann TM, Min J, McCarthy JB, Tuomanen EI. Adherence of Streptococcus pneumoniae to immobilized fibronectin. Infect Immun 1995; 63: 4317-4322.

32. Eberhard T, Ullberg M, Sjöström I, Kronvall G, Wiman B. Enhancement of t-PA mediated plasminogen activation by bacterial surface receptors. Fibrinolysis 1995; 9: 65-70.

33. Ullberg M, Karlsson I, Wiman B, Kronvall G. Two types of receptors for human plasminogen on group $\mathrm{G}$ streptococci. APMIS 1992; 100: 21-28.

34. Lottenberg R, Broder CC, Boyle MDP, Kain SJ, Schroeder BL, Curtis R. Cloning, sequence analysis and expression in Escherichia coli of a streptococcal plasmin receptor. $J$ Bacteriol 1992; 174: 5204-5210.

35. Broeseker TA, Boyle MDP, Lottenberg R. Characterization of the interaction of human plasmin with its specific receptor on a group A streptococcus. Microb Pathog 1988; 5: 19-27.

36. Zavzion B, White JH, Bramley AJ. Staphylococcus aureus stimulates urokinase-type plasminogen activator expression by bovine mammary cells. J Infect Dis 1997; 176: 1637-1640.

37. Sodeinde OA, Sample AK, Brubaker RR, Goguen JD. Plasminogen activator/coagulase gene of Yersinia pestis is responsible for degradation of plasmid-encoded outer membrane proteins. Infect Immun 1988; 56: 2749-2752. 